\title{
Corrected QT Interval as a Predictor of Outcomes in Acute Organophosphate Poisoning Cases
}

\author{
Aliaa Abd Elhakam Hodeib and Heba Kamel Khalifa ${ }^{1}$ \\ ${ }^{1}$ Department of Forensic Medicine and Clinical Toxicology, Faculty of Medicine, Tanta University, Tanta, Egypt.
}

\begin{abstract}
\begin{tabular}{lll}
\hline Abstract & Introduction: Acute organophosphate (OP) poisoning is a global health problem and responsible
\end{tabular} for many deaths worldwide every year. It acts by inhibition of acetylcholinesterase causing cholinergic crises that lead to muscarinic, nicotinic and central manifestations. One of the most serious complications of organophosphate exposure is cardiac toxicity including electrocardiogram changes.This study aimed to evaluate corrected QT interval as predictor of major outcome events which included mortality, need for mechanical ventilation, number of atropine and toxogonine ampoules and duration of hospital stay in acute organophosphate toxicity. Methods: The study recruited 98 patients suffering from acute OP poisoning, who were admitted to Tanta University Poison Control Unit. QTc interval length and the different outcomes of the patients were recorded. Results: Fifty five patients $(56.1 \%)$ showed a prolonged QTc interval. Significant statistical association was recorded between QTc interval and delay time, manner \& route of poisoning, severity of oranophosphrous toxicity and pseudocholinesterase level. Also, significant statistical association was recorded between QTc interval and need for mechanical ventilation, mortality, number of atropine \& toxogonine ampoules and duration of hospital stay. Conclusion: Finally, it was concluded that QTc interval could be a good predictor for outcomes of acute organophosphrous poisoning.
\end{abstract}

Key words Acute Organophosphate Toxicity, Electrocardiographic Changes, QTc, Ventilation, Mortality.

\section{Introduction}

$\mathrm{O}$ rganophosphates constitute a heterogeneous category of chemicals which designed for control of pests, weeds, or plant diseases. Their application is still the most accepted mean for plant protection from pests due to their low cost, high efficiency, and wide availability (Vijayakumar et al., 2011 \& Shadnia etal., 2019).

Organophosphate pesticides poisoning is a major health problem.The World Health Organization (WHO) estimated doubling in organophosphorous (OP) poisoning in deveoping countries during the past 10 years (Gunnell etal., 2007).

In Egypt, organophosphate intoxication is a common cause of morbidity and mortality despite appropriate treatment, it represents more than $50 \%$ of insecticide poisoning (Ibrahim et al., 2011 \& Pereska etal., 2019).

Organophosphate toxicity is mediated through acetylcholinesterase enzyme (AChE) inhibition. Subsequently, initial overstimulation of cholinergic synapses, neuromuscular junctions and central nervous system will occur, followed by paralysis. Cholinergic overload leads to muscarinic, nicotinic and central nervous system signs and symptoms (Kose et al., 2010 \& Pang etal., 2019).

The most common complication from organophosphate exposure is respiratory failure. Nevertheless, Cardiac complications such as various arrhythmias, conduction disturbances, hypertensionhypotension, and myocardial damage, have been reported. Such complications might be serious and are often fatal. However, they are potentially preventable if they are recognized early and treated adequately (BarMeir et al., 2007; Kose et al., 2009 and Cha et al., 2014).

The existing publications of organophosphate induced cardiac toxicity are limited. Furthermore, the extent, frequency, and pathogenesis of organophosphate induced cardiac toxicity have not been inconclusive, and sometimes conflicting results have been reported (Abuelfadl etal., 2015). 
The prolonged QT-interval is originated from intense and unequal sympathetic stimulation of myocardial fibers, also it has been observed in some cases of severe bradycardia or disease of the central nervous system. Therefore, both sympathetic and parasympathetic stimulation may cause QT-interval prolongation. Therefore it is important prognostically in many medical conditions, but its role in OP is not clear (Bar-Meir etal., 2007).

There is an increasing interest in medicine for measuring the severity of illness and predicting outcome to allow proper reserve allocation and therapeutic aggressiveness. (Henderson, 2004) Therefore, the current study was conducted to evaluate corrected QT interval as predictor of major outcome events (mortality, need for ventilation, number of atropine and toxogonine ampoules and duration of hospital stay) in acute organophosphate toxicity.

\section{Patients and methods}

This cohort study was performed at Poison Control Unit, Emergency Hospital, Tanta University. Data were gathered retrospectively from January 2019 to July 2019 and prospectively from August 2019 to November 2019. It was approved by Research Ethical Committee, Faculty of Medicine, Tanta University. All participants received detailed information concerning aims of research work, and informed consent was obtained from each participant or his relatives prior to commencement of the study. Privacy and confidentiality of patients' records and data was ascertained through coding system.

\section{Eligibility criteria}

Over the study period, ninety eight (98) patients exposed to organophosphate were included in this study. Diagnosis of acute organophosphate poisoning (OPP) was based on history of organophosphate exposure , characteristic organophosphate symptoms and signs, clinical improvement after atropine and oximes (toxogonin) administration and decrease in serum pseudocholinesterase enzyme levels (Karki et al., 2004 and Liu et al., 2012).Patients with history of cardiac diseases (rheumatic heart disease, atrioventricular arrhythmias, congestive cardiac failure, 2nd or 3rd heart block and ischemic heart disease) were excluded from the study. Furthermore, patients who received any medical treatment before admission together with patients of mixed exposure were similarly excluded. Patients with any pre-existing chronic diseases including; hypertension, diabetes, hepatic \& renal diseases and cancer were excluded as well.

For all patients' sociodemographic data (age, sex, education, residence, marital state and work) and toxicological data (route \& circumstances of poisoning and time delay) were retrieved and carefully examined. On admission clinical data included vital signs and level of consciousness (Glasgow Coma Scale, GCS) was obtained.

Electrocardiography (ECG) was recorded on admission, every 6 hours and when an abnormality was observed on cardiac monitor. The ECG was analyzed for rate, rhythm, axis, voltage, ST and T wave abnormalities, conduction defects, PR interval. Corrected QT interval (QTc) was estimated according to Bazett's formula; QTc $=\mathrm{QT} / \mathrm{vRR}$ (normally up to 0.44 second).

"The severity of symptoms and signs of acute OPP was graded according to Minton \& Murray (1988) into: Mild OPP; Fatigue, headache, blurred vision, dizziness, nausea, vomiting, excessive sweating, salivation, abdominal pain and tightness in chest. Moderate OPP; Symptoms of mild poisoning plus muscular fasciculation, weakness, inability to walk, chest crepitations and miosis. Severe OPP; Symptoms of moderate poisoning plus unconsciousness, flaccid paralysis, respiratory distress, cyanosis and marked miosis with loss of pupil reflexes."

Blood samples were collected after admission before administration of any medication , arterial and venous blood samples were obtained for blood gas analysis and for assessment of Liver enzymes, renal function , blood electrolytes level (Na \&K) and random blood sugar .The serum was separated and used for estimation of serum pseudocholinesterase level using butyrylthiocholine substrate, commercial kit supplied by Biodiagnostic, Egypt (normal value 5400-13200 U/L) (Kende and Bottger, 1967; Blawen et al., 1983).

The different outcomes of the patients were recorded. These included mortality, the need for mechanical ventilation, the length of hospital stay, and the total dose of atropine and/or obidoxime administered. Methods of Statistical analysis:

Data were fed to the computer and analyzed using IBM SPSS software package version 20.0. (Armonk, NY: IBM Corp). The Kolmogorov- Smirnov test was used to verify the normality of distribution of variables. Comparisons between groups for categorical variables were assessed using Chi-square test (Fisher or Monte Carlo). Student t-test was used to compare two groups for normally distributed quantitative variables while Mann Whitney test was used to compare between two groups for notnormally distributed quantitative variables. Significance of the obtained results was judged at the $5 \%$ level.

\section{Results}

During the study period, ninety eight patients have fulfilled the inclusion and exclusion criteria. Data of fifty patients were collected retrospectively and data of 48 were collected prospectively. All the prospective patients have accepted study participation.

Sociodemographic data of the participant patients was demonstrated in table 1 . The median age of the participants was 35 years. Females represented $33.7 \%$; while males represented $66.3 \%$ of the participants. The majority of patients were married and from rural areas $58.2 \%$ and $69.4 \%$ respectively. Regarding the educational level, $22.4 \%$ of the cases were illiterate, $26.5 \%$ could read and write and the remaining $51 \%$ were graduated from secondary schools. Farmers 
represented the highest present from participants $44.9 \%$ while students represented the lowest percent of participants 5.1\%.

Toxicological history and clinical characteristics of patients included in this study was tabulated in table 2 . An accidental poisoning was found in $51 \%$ of participants; while the remaining $49 \%$ were attempted suicidal. Ingestion was the main route of exposure (51 $\%)$. The median of time delay was 3 hours. Patients presented with mild toxicity were $48 \%$, while who presented with sever toxicity were $19.4 \%$. The range of pseudocholinesterase level was 10.8 - 11169 .

The studied group revealed a mean QTc interval of $0.48 \pm 0.05$ seconds (range $0.44-0.59$ seconds). Significant statistical association was recorded between QTc interval and severity of OP toxicity; manner \& route of poisoning, delay time and pseudocholinesterase level (Table 3).

Fifty five patients (56.1\%) showed a prolonged QTc interval. Both need for ventilation and mortality were noticed in patients with prolonged QTc interval rather than in patients with a normal QTc interval. Furthermore, significant statistical association was perceived between QTc interval and number of who need mechanical ventilation, mortality rate, atropine \& toxogonine ampoules and hospital stay period (Table 4).

It was observed that 8 patients $(21.05 \%)$ required intubation and mechanical ventilation assistance. Among those intubated patients, two patients died. Seven patients out of the intubated patients registered prolonged QTc interval. All of the intubated patients were suicidal attempts. Moreover, oral route was the main route of exposure (seven patients).

Table (1): Sociodemographic data of the studied patients with acute organophosphate poisoning $(n=98)$

\begin{tabular}{|c|c|}
\hline Characteristic variables & Median (Min. -Max.) \\
\hline Age (years) & $35(12.0-66)$ \\
\hline Characteristic variables & N (\%) \\
\hline \multicolumn{2}{|l|}{ Sex } \\
\hline $\begin{array}{l}\text { Male } \\
\text { Female }\end{array}$ & $\begin{array}{l}65(66.3 \%) \\
33(33.7 \%)\end{array}$ \\
\hline \multicolumn{2}{|l|}{ Marital Status } \\
\hline $\begin{array}{l}\text { Single } \\
\text { Married }\end{array}$ & $\begin{array}{l}41(41.8 \%) \\
57(58.2 \%)\end{array}$ \\
\hline \multicolumn{2}{|l|}{ Location } \\
\hline $\begin{array}{l}\text { Rural } \\
\text { Urban }\end{array}$ & $\begin{array}{l}68(69.4 \%) \\
30(30.6 \%)\end{array}$ \\
\hline \multicolumn{2}{|l|}{ Education } \\
\hline $\begin{array}{l}\text { Illiterate } \\
\text { Read and write } \\
\text { Secondary school }\end{array}$ & $\begin{array}{l}22(22.4 \%) \\
26(26.5 \%) \\
50(51 \%)\end{array}$ \\
\hline \multicolumn{2}{|l|}{ Work } \\
\hline $\begin{array}{l}\text { Unemployed } \\
\text { Farmer } \\
\text { Skilled worker } \\
\text { Housewife } \\
\text { Student } \\
\text { Employed } \\
\end{array}$ & $\begin{array}{l}19(19.4 \%) \\
44(44.9 \%) \\
15(15.3 \%) \\
8(8.2 \%) \\
5(5.1 \%) \\
7(7.1 \%) \\
\end{array}$ \\
\hline
\end{tabular}

n: number; SD: standard deviation; Min: minimum; Max:maximum 
Table (2): Toxicological history and clinical characteristics of the studied patients with acute organophosphrous poisoning $(\mathbf{n}=98)$

\begin{tabular}{|c|c|c|}
\hline Toxicological history & & \\
\hline Mode of poisoning & N (\%) & \\
\hline $\begin{array}{l}\text { Accidental } \\
\text { Suicidal }\end{array}$ & $\begin{array}{l}50(51 \%) \\
48(49 \%)\end{array}$ & \\
\hline Route of administration & N (\%) & \\
\hline $\begin{array}{l}\text { Ingestion } \\
\text { Mixed ingestion and inhalation } \\
\text { Unknown }\end{array}$ & $\begin{array}{l}51(52 \%) \\
46(46.9 \%) \\
1(1 \%)\end{array}$ & \\
\hline $\begin{array}{l}\text { Delay time } \\
\text { (hours) }\end{array}$ & $\begin{array}{l}\text { Median (Min. - Max.) } \\
3(0.5-24)\end{array}$ & \\
\hline Severity of toxicity & N (\%) & \\
\hline $\begin{array}{l}\text { Mild } \\
\text { Moderate } \\
\text { Severe }\end{array}$ & $\begin{array}{l}47(48 \%) \\
32(32.7 \%) \\
19(19.4 \%)\end{array}$ & \\
\hline Pseudocholinesterase level (U/ml) & Median (Min. - Max.) & \\
\hline & $2817.5(10.8-11169)$ & \\
\hline & Mean \pm SD & Median (Min. - Max.) \\
\hline $\begin{array}{c}\text { Corrected QT interval } \\
\text { (sec) }\end{array}$ & $0.48 \pm 0.05$ & $\begin{array}{l}0.48 \\
(0.44-0.59)\end{array}$ \\
\hline
\end{tabular}

n: number; SD: standard deviation; Min: minimum; Max:maximum : QTc (sec); U/mL: Units per milliliter

Table (3): Comparison between patients with normal and prolonged QTc intervals regarding toxicological and clinical data by Chi square and Mann Whitney tests $(\mathbf{n}=98)$

\begin{tabular}{|c|c|c|c|c|}
\hline & \multicolumn{2}{|l|}{ QTc (sec) } & \multirow[t]{2}{*}{ Test of Sig. } & \multirow[t]{2}{*}{$\mathbf{P}$} \\
\hline & $\begin{array}{l}0.44 \\
(n=43) \\
43.87 \%\end{array}$ & $\begin{array}{l}>0.44 \\
(n=55) 56.1 \%\end{array}$ & & \\
\hline \multicolumn{5}{|l|}{ Severity of toxicity } \\
\hline Mild & $43(100 \%)$ & $4(7.3 \%)$ & \multirow{3}{*}{$\begin{array}{l}\chi^{2}= \\
83.139^{*}\end{array}$} & \multirow[t]{3}{*}{$<0.001^{*}$} \\
\hline Moderate & $0(0 \%)$ & $32(58.2 \%)$ & & \\
\hline Severe & $0(0 \%)$ & $19(34.5 \%)$ & & \\
\hline \multicolumn{5}{|l|}{ Manner } \\
\hline Accidental & $26(60.5 \%)$ & $24(43.6 \%)$ & \multirow{2}{*}{$\begin{array}{l}\chi^{2}= \\
2.735\end{array}$} & \multirow[t]{2}{*}{0.098} \\
\hline Suicidal & $17(39.5 \%)$ & $31(56.4 \%)$ & & \\
\hline \multicolumn{5}{|l|}{ Route } \\
\hline Ingestion & $20(46.5 \%)$ & $31(56.4 \%)$ & \multirow{3}{*}{$\begin{array}{l}\chi^{2}= \\
1.867^{*}\end{array}$} & \multirow[t]{3}{*}{0.366} \\
\hline Combined & $23(53.5 \%)$ & $23(41.8 \%)$ & & \\
\hline Unknown & $0(0 \%)$ & $1(1.8 \%)$ & & \\
\hline \multicolumn{5}{|l|}{ Delay (hrs) } \\
\hline Median (Min. -Max.) & $3(0.5-10)$ & $4(1-24)$ & $\mathrm{U}=948.0$ & 0.120 \\
\hline \multicolumn{5}{|l|}{ Pseudocholinesterase level (U/ml) } \\
\hline Median (Min. -Max.) & $3500(846$ & $2578(10.8-4$ & $\mathrm{U}=737.50^{\prime}$ & $0.001 *$ \\
\hline
\end{tabular}

$\chi^{2}$ : Chi square test, U: Mann Whitney test, $p: p$ value for association between QTc (sec) and different parameters, *: Statistically significant at $p \leq 0.05$ 
Table (4): Comparison between patients with normal and prolonged QTc intervals according to different outcomes by Chi square and Mann Whitney tests $(\mathbf{n}=98)$

\begin{tabular}{|c|c|c|c|c|}
\hline & \multicolumn{2}{|l|}{ QTc (sec) } & \multirow[t]{2}{*}{ Test of Sig. } & \multirow[t]{2}{*}{$\mathbf{p}$} \\
\hline & $\begin{array}{l}0.44 \\
(n=43)\end{array}$ & $\begin{array}{l}>0.44 \\
(n=55)\end{array}$ & & \\
\hline \multicolumn{5}{|l|}{ Ventilation } \\
\hline No & $43(100 \%)$ & $46(83.6 \%)$ & \multirow{2}{*}{$\chi^{2}=7.748^{*}$} & \multirow[t]{2}{*}{$0.004^{*}$} \\
\hline Yes & $0(0 \%)$ & $9(16.4 \%)$ & & \\
\hline \multicolumn{5}{|l|}{ Mortality } \\
\hline No & $43(100 \%)$ & $48(87.3 \%)$ & \multirow{2}{*}{$\begin{array}{l}\chi^{2}= \\
5.894^{*}\end{array}$} & \multirow{2}{*}{$0.017^{*}$} \\
\hline Yes & $0(0 \%)$ & $7(12.7 \%)$ & & \\
\hline \multicolumn{5}{|c|}{ Number of Atropine Ampoules } \\
\hline Median (Min. - Max.) & $2(1-33)$ & $10(0-88)$ & $\mathrm{U}=526.0^{*}$ & $<0.001^{*}$ \\
\hline \multicolumn{5}{|c|}{ Number of Toxogonin Ampoules } \\
\hline Median (Min. - Max.) & $0(0-11)$ & $4(0-30)$ & $\mathrm{U}=239.50^{*}$ & $<0.001^{*}$ \\
\hline \multicolumn{5}{|l|}{ Hospital Stay (days) } \\
\hline Median (Min. - Max.) & $0.5(0.3-3)$ & $2(0.3-11)$ & $\mathrm{U}=366.50^{*}$ & $<0.001^{*}$ \\
\hline
\end{tabular}

$\chi^{2}$ : Chi square test, $U$ : Mann Whitney test, $p: p$ value for association between QTc (sec) and different parameters, *: Statistically significant at $p \leq 0.05$

\section{Discussion}

Organophosphrous poisoning is a major global health problem and high mortality is seen in resource-poor settings. The present study was designed to assess the effectiveness of corrected QT interval to predict the major outcome events of OP poisoning (mortality, need for ventilation, atropine \& toxogonine ampoules and hospital stay period). In order to achieve this target toxicological, clinical data and major outcome events were analyzed against corrected QT interval in acute organophosphate poisoned patients.

Ludomirsky et al. (1982) described three phases of cardiac toxicity after organophosphate poisoning. The first phase is a brief period of increased sympathetic tone. Phase 2 is a prolonged period of parasympathetic activity and phase 3 in which QT prolongation is followed by torsade de pointes, ventricular tachycardia, and then ventricular fibrillation.

In the current study 55 (56.1\%) patients showed a prolonged QTc interval. Comparable studies by Karki et al. (2004), Grmec et al. (2004), Shadnia et al. (2009) and Lakhair et al. (2012) signified prolonged QTc interval in 39\%, 37.8\%, 65\%, 59.5\% and 67\% of OP poisoned cases respectively. In addition Abdelnaby (2018) reported an acute organophosphrous poisoned patient presented with a prolonged QT interval and acute atrial fibrillation. The exact cellular mechanism of OP induced QT prolongation are not fully understood. It may involve inhibition of potassium outward channels. The ensuing intracellular surplus of positive ions delays ventricular repolarization (thus prolonging the QT interval) and may trigger early after-depolarizations (EADs). These EADs, may reach threshold amplitude and trigger ventricular arrhythmias (Viskin, 2000 and Khan \& Gowda, 2004).

The results obtained in this study pointed to association between QTc interval and OPP severity, serum cholinesterase level, mortality, need for ventilation, number of atropine \& toxogonine ampoules and duration of hospital stay. Data reported in previous comparable study designs displayed conflicting results. For example, significant association was noticed between QTc interval and both period of hospital stay, atropine requirements and respiratory failure with severe poisoning (Grmec et al., 2004 and Shadnia et al., 2009). Contradictory to these results, no statistically significant association could be found between QTc interval and either poison severity score or blood cholinesterase level (Baydin et al., 2007 and Akdur et al., 2010)

In the current study, it was anticipated to find significant statistical association between QTc interval and need for mechanical ventilation. Where, it was observed that 9 patients required mechanical ventilation assistance, all of them registered prolonged QTc interval. Previous literatures supported this finding by identifying respiratory failure in patients with QTc interval prolongation rather than in those with normal QTc interval in OPP (Grmec et al., 2004).

In the current study, $7.14 \%$ from patients died, all of them registered prolonged QTc interval. Such finding correlates with Chuang et al. (1996) who reported that OP exposed patients with QTc interval prolongation had a higher mortality ratio, compared with those without QTc interval prolongation. Moreover, Shadnia et al. (2009) described significantly higher mortality rate in the prolonged QTc OP exposed patients than in normal QTc OP exposed patients.

It was striking to find that all of the ventilated and died patients were suicidal attempts and classified as severe grade organophosphate toxicity. Furthermore, the main route of exposure in the dead patients was the oral route together with prolonged QTc interval. 
From this study, it could be concluded that, in OP exposed patients, QTc interval could be considered as good predictor for mortality, need for ventilation and prolonged hospital stay. Suicidal attempts, severe organophosphate intoxication, oral route of exposure together with prolonged QTc interval are alarming signs of need for ventilation and mortality.

Finally, it is recommended to consider QTc interval as an easy and applicable bedside parameter that might help toxicologists to identify advanced grade OP poisoning patients in initial assessment in emergency department. Organophosphate poisoned patients who are presented by suicidal attempts, severe organophosphate intoxication, oral route of exposure and prolonged QTc interval should be managed as high risk patients. Regarding the hospital burden, it could be limited by decreasing number of patients need intensive care unit admission by the exclusion of both mild and moderate cases.

The principal limitation of the current study is its small sample size precipitated by the wide range of inclusion and exclusion criteria. Moreover, name of the used organophosphates could not be clearly determined.

\section{References}

Abdelnaby MH (2018): Acute Atrial Fibrillation Induced by Organophosphorus Poisoning: Case Report. Journal of Clinical Toxicology. 8:1.

Abuelfadl AA, Shahin MM and Alghazaly GM (2015): Corrected QT as a Simple Tool for Prediction of Need for Ventilation and Mortality in Acute Organophosphate Poisoning. Mansoura Journal of Forensic Medicine and Clinical Toxicology. 23(2): 85-97 XMLPDF (28.27 MB) DOI: 10.21608/MJFMCT.2015.47282

Akdur O, Durukan P, Ozkan S, et al., (2010): Poisoning severity score, Glasgow coma scale, corrected QT interval in acute organophosphate poisoning. Human and Experimental Toxicology, 29 (5): 419-425.

Bar-Meir E, Schein O, Eisenkraft A, Rubinshtein R, Grubstein A, et al. (2007): Guidelines for treating cardiac manifestations of organophosphates poisoning with special emphasis on long QT and Torsades De Pointes. Crit Rev Toxico, 137: 279-285.

Baydin A, Aygun A, Yazici M, et al., (2007): Is there a relationship between the blood cholinesterase and QTc interval in the patient with acute organophosphate poisoning? Int J ClinPract, (61) 6: 927-930

Blawen D, Poppe DH and Trischler WA. (1983): Serum acetylcholinesterase assay. J. Clin. Chem, Biochem. 21:381-386.

Cha YS, Kim H, Go J, et al., (2014): Features of myocardial injury in severe organophosphate poisoning. Clin Toxicol (Phila), 52:873-879.
Chuang FR, Jang SW, Lin JL, et al., (1996) : QTc prolongation indicates a poor prognosis in patients with organophosphate poisoning. Am J Emerg Med, 14: 451-3.

Grmec S, Mally S and Klemen P (2004): Glasgow Coma Scale score and QTc interval in the prognosis of organophosphate poisoning. AcadEmerg Med 2004; 11: 925-30.

Gunnell D, Eddleston M, Phillips MR, et al. (2007): The globaldistribution of fatal pesticide selfpoisoning: Systematic review. BMC Public Health, 27:357.

Henderson W (2004): APACHE: An evaluation. Paedagog. Hist, 40: 435-453.

Ibrahim MA, El Masry MK, Moustafa AA, et al., (2011): Comparison of the accuracy of two scoring systems in predicting the outcome of organophosphate intoxicated patients admitted to intensive care unit (ICU). Egypt. J. Forensic Sci. 1: 41-47

Karki JA, Ansari S, Bhandary S, et al., (2004): Cardiac and electrocardiographic manifestations of acute organophosphate poisoning. Singapore Med J; 45(8): 385-389.

Kende M and Bottger R. (1967): Eine kinetische Methode zur Bestimmung der Aktivität der Pseudocholinesterase (Acylcholin-acylhydrolase 3.1.1.8.). Kiln. Wschr. 45: 325-327.

Khan IA and Gowda RM (2004): Novel therapeutics for treatment of long-QT syndrome and torsade de pointes. Int. J. Cardiol, 95(1):1-6.

Kose A, Gunay N, Yildirim C, et al., (2009): Department of EmeCardiac damage in acute organophosphate poisoning in rats: Effects of atropine and pralidoxime. Am J Emerg Med, 27: 169-175.

Kose A, Gunay N, Kose B, et al., (2010): Effects of atropine and pralidoxime pretreatment on serum and cardiac oxidative stress parameters in acute dichlorvos toxicity in rats. Pest Biochem Physiol, 97:249- 55.

Lakhair M A, Shaikh M A, Kumar S, et al., (2012): Frequency of Various Clinical and Electrocardiac Manifestation in Patients with Acute Organophosphorous Compound (OPC) Poisoning. JLUMHS, 11 (01): 34-38.

Liu SH, Lin JL, Weng CH, et al., (2012): Heart RateCorrected QT Interval Helps Predict Mortality after Intentional Organophosphate Poisoning. PLOS

ONE, https://doi.org/10.1371/journal.pone.0036576

Ludomirsky A, Klein H, Sarelli P, et al. (1982): Q-T prolongation and polymorphous (torsade de pointes) ventricular arrhythmias associated with organophsphorus insecticide poisoning. Am J Cardiol; 49:1654-8. 
Minton NA, Murray VS (1988): A review of organophosphate poisoning. Med Toxicol Adverse Drug Exp, 3(5):350-75.

Pang L, Liu J, Li W, et al., (2019): Serum ubiquitin C-terminal hydrolase L1 predicts cognitive impairment in patients with acute organophosphorus pesticide poisoning. J Clin Lab Anal. 33(7): e22947. PMCID: PMC6757117

Pereska Z, Chaparoska D, Bekarovski N, et al., (2019): Pulmonary thrombosis in acute organophosphate poisoning-Case report and literature overview of prothrombotic preconditioning in organophosphate toxicity. Toxicol. 6: 550-555. PMCID: PMC6587046

Shadnia S, Okazia A, Akhlaghia N, et al., (2009): Prognostic Value of Long QT Interval in Acute and Severe Organophosphate PoisoningJournal Of Medical Toxicology, (5) 4: 169-199.

Shadnia S, Zamani N, Nikpour S, et al., (2019): Atropine Challenge Test in Screening the Organophosphorus Poisoning Cases with Atypical Presentation; a Brief Report. Arch Acad Emerg, 7(1): e46. PMCID: PMC6785209.

Vijayakumar S, kumar EA and Rao M (2011): A Prospective Study on Electrocardiographic Findings of Patients with Organophosphorus Poisoning. Cardiovascular Toxicology, 11(2): 113-117.

Viskin $\mathrm{S}$

(2000):

CardiacpacinginthelongQTsyndrome:Review of available data and practical recommendations. J. Cardiovasc. Electrophysiol, 11(5):593-600.

\section{الملخص العربى}

\section{الفاصل الزمني المصحح QTc كمتبي بالنتائج في حالات التسمم الحاد بالمبيدات الفوسفورية العضوية}

\section{علياء عبد الحكم هديب و هبه كامل خليفه'}

$$
\begin{aligned}
& \text { يمثل التسمم الحاد بالفوسفات العضوي مشكلة صحيه عالمية وهو المسؤل عن العديد من الوفيات في جميع أنحاء العالم كل عام. } \\
& \text { وتعمل المبيدات العضوية الفسفورية عن طريق تثبيط أستيل كولينستراز مما يسبب أزمات كولينية تؤدي إلى اعراض مسكارينية ونيكوتينية ومركزية. } \\
& \text { تعد سمية القلب واحدة من أخطر مضاعفات التعرض للفوسفات العضوي بما في ذلك التغيرات الكهربائيه لرسم القلب. } \\
& \text { هدفت هذه الدراسة إلى تقييم فاصل QTc المصحح كمتنبئ بالنتائج الرئيسية في حالات التسمم الحاد بالمبيدات لبعضوية } \\
& \text { الفسفورية و هي معدل الوفيات ، الحاجة إلى التنفس الصناعي ، وعدد أمبولات الأتروبين و التوكسوجونين ومدة الإقامة في المستشفى في } \\
& \text { سمية الفوسفات العضوي الحلاد. } \\
& \text { وقد أجريت الدراسةعلي } 9 \text { و مريضا يعانون من تسمم الفوسفات العضوي الحاد ، الذين تم قبولمم في وحدة علاج التسمم بجامعة }
\end{aligned}
$$

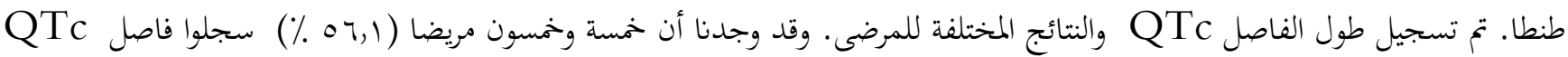

$$
\begin{aligned}
& \text { مطول و قد تم تسجيل علاقه إحصائية كبيرة بين الفاصل الزمني QTC المطول و كل من الوقت الفاصل بين التسمم و الوصول الي المركز, } \\
& \text { كيفيه التسمم ؛ طريقه تناول المركب ، شدة سمية الفوسفات العضوي و مستوى الكولينستراز الكاذب. } \\
& \text { وقد سجلت ايضا علاقه إحصائية كبيرة بين الفاصل الزمني QTC المطول و كلا من الحاجة إلى التنفس الصناعي ـ معدل الوفيات, } \\
& \text { عدد أمبولات الأتروبين والتوكسوجونين و مده البقاء في المستشفى. } \\
& \text { وأخيرا ، تم استنتاج أن الفاصل الزمني QTc المطول يمكن أن يكون مؤشرا جيدا لنتائج التسمم الفوسفوري العضوي الحاد. }
\end{aligned}
$$

